\title{
Effect of Manganese on Calcification of Bone
}

\author{
By E. TAL AND K. GUGGENHEIM \\ Laboratory of Nutrition, Hebrew University-Hadassah Medical School, Jerusalem, Israel
}

(Received 30 June 1964)

\begin{abstract}
1. Young mice were maintained on a basal diet composed of meat, which is poor in both manganese and calcium. 2. The addition of small amounts $(2 \cdot 5-5 \cdot 0 \mathrm{mg} . / \mathrm{kg}$. of meat) of manganese improved weight gain and calcification of bone and decreased incorporation of injected radiocalcium into bone. 3. Prolonged treatment with larger amounts $(10 \cdot 0-25 \cdot 0 \mathrm{mg} . / \mathrm{kg}$. of meat) of manganese depressed growth, induced defective calcification of bone and increased incorporation of radiocalcium into bone.
\end{abstract}

It is well known that dietary lack of manganese induces skeletal abnormalities, including generalized rarefaction of bone, that are preventable by appropriate manganese supplementation (Underwood, 1962). These findings were reported in animals that had subsisted on diets containing sufficient or abundant amounts of calcium. Recently, manganese has been found to increase bone ash of mice subsisting on a diet composed of ox muscle only, which is poor in calcium as well as in manganese (Ilan, Schwartz \& Guggenheim, 1961). Young mice maintained for 6 weeks on unsupplemented meat developed a severe bone disorder. The ash content of the bone was markedly decreased, and osteoporosis could be demonstrated both radiologically (Ilan et al. 1961) and histologically (Ulmansky, 1964). The addition of $2.5 \mathrm{mg}$. of manganese $/ \mathrm{kg}$. of meat increased bone ash from $46 \cdot 9 \mathrm{~g} . / 100 \mathrm{~g}$. of dry fat-free bone to $55 \cdot 1 \mathrm{~g} . / 100 \mathrm{~g}$., in spite of the fact that the diet was very poor in calcium. The effect of larger amounts of manganese is reported in the present paper. Mice were kept for various times on ox meat to which different amounts of manganese $(2 \cdot 5-25 \cdot 0 \mathrm{mg}$. $/ \mathrm{kg}$.) were added. Their femurs were then analysed for bone ash, calcium, phosphorus and manganese. The incorporation of radioactive calcium in bone was also determined.

\section{METHODS}

Sixteen groups of 24 male Swiss mice, 3 weeks old (10-13g.), were used. Their diet consisted of raw lean ox muscle, which was offered either unsupplemented ('negative' control), or supplemented with $2 \cdot 5,5 \cdot 0,10 \cdot 0$ or $25 \cdot 0 \mathrm{mg}$. of manganese (as $\mathrm{MnSO}_{4}$ ) $/ \mathrm{kg}$. or with $3.6 \mathrm{~g}$. of calcium (as $\mathrm{CaCO}_{3}$ )/kg. ('positive' control). Femurs of mice fed on meat and given a similar supplement of calcium $(3 \cdot 3 \mathrm{~g} . / \mathrm{kg}$.) were previously found to contain a normal percentage of ash (Ilan et al. 1961). The calcium content of the meat was examined in 12 samples and found to be 95 (s.F.M. \pm 5.9 ) $\mathrm{mg} \cdot / \mathrm{kg}$.
Four groups ('negative' and 'positive' controls and mice supplemented with $10 \cdot 0$ and $25.0 \mathrm{mg}$. of manganese $/ \mathrm{kg}$. of meat) were killed after 2 weeks. 'Negative' and 'positive' controls and four groups supplemented with the four different concentrations of manganese were killed after 4 and 6 weeks respectively. The femurs were cleaned from adherent tissue and weighed. They were then broken, extracted for $6 \mathrm{hr}$. with ethanol in a Soxhlet apparatus, dried to constant weight and ashed at $600^{\circ}$. The calcium (Baron \& Bell, 1959), phosphorus (Fiske \& Subbarrow, 1925) and manganese (Gates \& Ellis, 1947) contents of the ash were determined. Determination of phosphorus and manganese were performed in 18 mice only of each group. Measured portions from the ash of three pairs of femurs were pooled. The values in the Tables thus indicate means \pm s.e.M. of six samples each comprising three pairs of femurs.

In six animals of each group the incorporation of radioactive calcium was studied. These mice received a dose of ${ }^{45} \mathrm{CaCl}_{2}$ subcutaneously at the end of the experimental period $(0.1 \mu \mathrm{c}$ in $1.0 \mathrm{mg}$. of calcium $/ 10 \mathrm{~g}$. body wt.). On the following day the animals were killed and their femurs ashed at $600^{\circ}$. The ash was dissolved in $1 \mathrm{~N}-\mathrm{HCl}$ and a measured portion was taken for determination of radioactivity. The results are expressed as $\mu \mathrm{g}$. of the dose administered per $\mathrm{g}$. of dry fat-free bone or per $100 \mathrm{mg}$. of bone calcium.

\section{RESULTS}

Table 1 presents results obtained after an experimental period of 2 weeks. The mice that were fed on a diet supplemented with calcium increased their weight more than the mice fed on the unsupplemented diet. The addition of manganese to the meat also produced an increase in weight, but this was not as great as that with calcium. The calcium supplement significantly $(P<0.01)$ increased bone ash and the concentrations of calcium and phosphorus in both ash and in dry fat-free bone, but decreased the incorporation of radioactive calcium in bone $(P<0.01)$. A similar, though smaller, effect on bone was observed when meat was supplemented with $25 \mathrm{mg}$. of manganese/kg., whereas 
Table 1. Composition of bones and uptake of radioactive calcium by femurs of mice maintained for 2 weeks on a meat diet

Experimental details are given in the text. The results are given as means \pm s.t.M.

Weight increase (g.)
Weight of femurs (m

Ash:

(mg.)
(\% of dry fat-free bone)
$\mathrm{Ca}:$
( $\%$ of ash)
(\% of dry fat-free bone)
Ca incorporated:
( $\mu \mathrm{g} . / \mathrm{g}$. of dry fat-free bone)
( $\mu \mathrm{g} . / 100 \mathrm{mg}$. of bone Ca)
P:
(\% of ash)
(\% of dry fat-free bone)
$\mathrm{Mn:}$
(mg./100g. of ash)
(mg./ $/ 100 \mathrm{~g}$. of dry fat-free
bone)

\begin{tabular}{|c|c|c|c|c|c|}
\hline ... None & $\begin{array}{c}10.0 \mathrm{mg} . \text { of } \\
\mathrm{Mn} / \mathrm{kg} \text {. of meat }\end{array}$ & $\begin{array}{c}25.0 \mathrm{mg} . \text { of } \\
\mathrm{Mn} / \mathrm{kg} \text {. of meat }\end{array}$ & $\begin{array}{c}3600 \mathrm{mg} . \text { of } \\
\mathrm{Ca} / \mathrm{kg} \text {. of meat }\end{array}$ & $\begin{array}{l}\text { No. of pairs } \\
\text { of femurs in } \\
\text { each sample }\end{array}$ & $\begin{array}{c}\text { No. of } \\
\text { samples in } \\
\text { each mean }\end{array}$ \\
\hline $\begin{array}{r}4 \cdot 6 \pm 1 \cdot 7 \\
68 \pm 5 \cdot 5\end{array}$ & $\begin{array}{r}5 \cdot 5 \pm 0 \cdot 8 \\
77 \pm 5 \cdot 3\end{array}$ & $\begin{array}{r}6 \cdot 5 \pm 1 \cdot 0 \\
85 \pm 3.5\end{array}$ & $\begin{array}{r}7 \cdot 8 \pm 0.9 \\
98 \pm 5 \cdot 6\end{array}$ & $\overline{1}$ & $\begin{array}{l}24 \\
24\end{array}$ \\
\hline $\begin{array}{l}13 \cdot 7 \pm 1 \cdot 3 \\
42 \cdot 1 \pm 0 \cdot 63\end{array}$ & $\begin{array}{l}15 \cdot 5 \pm 1 \cdot 1 \\
42 \cdot 2 \pm 1 \cdot 55\end{array}$ & $\begin{array}{l}20 \cdot 2 \pm 1 \cdot 2 \\
48 \cdot 8 \pm 0 \cdot 49\end{array}$ & $\begin{array}{l}28 \cdot 4 \pm 2 \cdot 2 \\
53 \cdot 6 \pm 0 \cdot 71\end{array}$ & $\begin{array}{l}1 \\
1\end{array}$ & $\begin{array}{l}24 \\
24\end{array}$ \\
\hline $\begin{array}{l}30.4 \pm 0.21 \\
12.7 \pm 0.18\end{array}$ & $\begin{array}{l}29.5 \pm 0.15 \\
12.4 \pm 0.20\end{array}$ & $\begin{array}{l}32 \cdot 1 \pm 0 \cdot 14 \\
15 \cdot 6 \pm 0.22\end{array}$ & $\begin{array}{l}35 \cdot 1 \pm 0.10 \\
18.9 \pm 0.23\end{array}$ & $\begin{array}{l}1 \\
1\end{array}$ & $\begin{array}{l}24 \\
25\end{array}$ \\
\hline $\begin{array}{l}78 \pm 0.55 \\
62 \pm 0.22\end{array}$ & $\begin{array}{l}80 \pm 0.53 \\
64 \pm 0.32\end{array}$ & $\begin{array}{l}77 \pm 0.66 \\
53 \pm 0.48\end{array}$ & $\begin{array}{l}56 \pm 0.21 \\
30 \pm 0.53\end{array}$ & $\begin{array}{l}1 \\
1\end{array}$ & $\begin{array}{l}6 \\
6\end{array}$ \\
\hline $\begin{array}{r}15 \cdot 7 \pm 0 \cdot 17 \\
6 \cdot 6 \pm 0 \cdot 12\end{array}$ & $\begin{array}{r}14 \cdot 8 \pm 0 \cdot 10 \\
6 \cdot 3 \pm 0 \cdot 15\end{array}$ & $\begin{array}{r}16 \cdot 3 \pm 0.12 \\
8 \cdot 0 \pm 0.13\end{array}$ & $\begin{array}{r}17 \cdot 7 \pm 0 \cdot 15 \\
9 \cdot 6 \pm 0 \cdot 17\end{array}$ & $\begin{array}{l}\mathbf{3} \\
\mathbf{3}\end{array}$ & $\begin{array}{l}6 \\
6\end{array}$ \\
\hline $490 \pm 14$ & $788 \pm 12$ & $811 \pm 13$ & $411 \pm 12$ & 3 & 6 \\
\hline $203 \pm 27$ & $332 \pm 22$ & $389 \pm 24$ & $219 \pm 22$ & 3 & 6 \\
\hline
\end{tabular}

Table 2. Composition of bones and uptake of radioactive calcium by femurs of mice maintained for 4 weeks on a meat diet

Experimental details are given in the text. The results are given as means \pm S.F.M.

\begin{tabular}{|c|c|c|c|c|c|c|c|c|}
\hline Supplement & None & $\begin{array}{c}\mathrm{Mn} / \mathrm{kg} \text {. of } \\
\text { meat }\end{array}$ & $\begin{array}{c}\mathrm{Mn} / \mathrm{kg} \text {. of } \\
\text { meat }\end{array}$ & $\begin{array}{c}\mathrm{Mn} / \mathrm{kg} \text {. of } \\
\text { meat }\end{array}$ & $\begin{array}{c}\mathrm{Mn} / \mathrm{kg} \text {. of } \\
\text { meat }\end{array}$ & $\begin{array}{l}\mathrm{Ca} / \mathrm{kg} \text {. of } \\
\text { meat }\end{array}$ & $\begin{array}{c}\text { each } \\
\text { sample }\end{array}$ & $\begin{array}{r}\text { in each } \\
\text { mean }\end{array}$ \\
\hline $\begin{array}{l}\text { Weight increase (g.) } \\
\text { Weight of femurs (mg.) }\end{array}$ & $\begin{array}{r}4 \cdot 4 \pm 1 \cdot 3 \\
97 \pm 4 \cdot 9\end{array}$ & $\begin{array}{r}7 \cdot 0 \pm 1 \cdot 2 \\
107 \pm 9 \cdot 0\end{array}$ & $\begin{array}{r}6 \cdot 0 \pm 0 \cdot 9 \\
97 \pm 9 \cdot 7\end{array}$ & $\begin{array}{r}3 \cdot 9 \pm 0 \cdot 8 \\
95 \pm 7 \cdot 3\end{array}$ & $\begin{array}{r}4 \cdot 2 \pm 0 \cdot 8 \\
111 \pm 8 \cdot 2\end{array}$ & $\begin{array}{r}9 \cdot 3 \pm 1 \cdot 5 \\
129 \pm 9 \cdot 5\end{array}$ & $\overline{1}$ & $\begin{array}{l}24 \\
24\end{array}$ \\
\hline Ash: & & & & & & & & \\
\hline $\begin{array}{l}\text { (mg.) } \\
\text { (\% of dry fat-free } \\
\text { bone) }\end{array}$ & $\begin{array}{l}19 \cdot 0 \pm 3 \cdot 6 \\
40 \cdot 8 \pm 0 \cdot 48\end{array}$ & $\begin{array}{l}23 \cdot 9 \pm 1 \cdot 8 \\
48 \cdot 1 \pm 0 \cdot 45\end{array}$ & $\begin{array}{l}21 \cdot 1 \pm 1 \cdot 7 \\
47 \cdot 0 \pm 0 \cdot 57\end{array}$ & $\begin{array}{l}20 \cdot 9 \pm 3 \cdot 2 \\
45 \cdot 4 \pm 0 \cdot 86\end{array}$ & $\begin{array}{l}23 \cdot 0 \pm 5 \cdot 0 \\
43 \cdot 1 \pm 0 \cdot 93\end{array}$ & $\begin{array}{l}43 \cdot 5 \pm 3 \cdot 6 \\
59 \cdot 6 \pm 1 \cdot 10\end{array}$ & $\begin{array}{l}1 \\
1\end{array}$ & $\begin{array}{l}24 \\
24\end{array}$ \\
\hline $\mathrm{Ca}:$ & & & & & & & & \\
\hline $\begin{array}{l}\text { (\% of ash) } \\
\text { (\% of dry fat-free } \\
\text { bone) }\end{array}$ & $\begin{array}{l}28 \cdot 9 \pm 0 \cdot 15 \\
11 \cdot 6 \pm 0 \cdot 18\end{array}$ & $\begin{array}{l}32 \cdot 3 \pm 0 \cdot 22 \\
15 \cdot 4 \pm 0 \cdot 20\end{array}$ & $\begin{array}{l}32 \cdot 3 \pm 0 \cdot 17 \\
15 \cdot 3 \pm 0 \cdot 10\end{array}$ & $\begin{array}{l}32 \cdot 5 \pm 0 \cdot 16 \\
14 \cdot 7 \pm 0 \cdot 12\end{array}$ & $\begin{array}{l}31 \cdot 3 \pm 0 \cdot 16 \\
13 \cdot 6 \pm 0 \cdot 15\end{array}$ & $\begin{array}{l}37 \cdot 4 \pm 0 \cdot 18 \\
22 \cdot 6 \pm 0 \cdot 19\end{array}$ & $\begin{array}{l}1 \\
1\end{array}$ & $\begin{array}{l}24 \\
24\end{array}$ \\
\hline $\begin{array}{l}\text { Ca incorporated: } \\
\text { ( } \mu \mathrm{g} \cdot / \mathrm{g} . \text { of dry fat. } \\
\text { free bone) }\end{array}$ & $73 \pm 0.43$ & $67 \pm 0 \cdot 41$ & $70 \pm 0.53$ & $61 \pm 0.38$ & $67 \pm 0.44$ & $44 \pm 0.59$ & 1 & 6 \\
\hline $\begin{array}{l}\text { ( } \mu \mathrm{g} . / 100 \mathrm{mg} . \text { of } \\
\text { bone Ca) }\end{array}$ & $62 \pm 0.53$ & $42 \pm 0.39$ & $46 \pm 0 \cdot 40$ & $40 \pm 0.52$ & $47 \pm 0.35$ & $20 \pm 0 \cdot 38$ & 1 & 6 \\
\hline $\mathbf{P :}$ & & & & & & & & \\
\hline $\begin{array}{l}\text { (\% of ash) } \\
\text { (\% of dry fat-free } \\
\text { bone) }\end{array}$ & $\begin{array}{r}15 \cdot 0 \pm 0 \cdot 18 \\
6 \cdot 0 \pm 0 \cdot 13\end{array}$ & $\begin{array}{r}16 \cdot 7 \pm 0 \cdot 12 \\
8 \cdot 5 \pm 0.15\end{array}$ & $\begin{array}{r}16 \cdot 6 \pm 0.15 \\
7 \cdot 8 \pm 0 \cdot 17\end{array}$ & $\begin{array}{r}15 \cdot 9 \pm 0 \cdot 13 \\
7 \cdot 1 \pm 0 \cdot 18\end{array}$ & $\begin{array}{r}15 \cdot 7 \pm 0 \cdot 14 \\
7 \cdot 0 \pm 0 \cdot 11\end{array}$ & $\begin{array}{l}18 \cdot 8 \pm 0 \cdot 19 \\
11 \cdot 5 \pm 0 \cdot 16\end{array}$ & $\begin{array}{l}\mathbf{3} \\
\mathbf{3}\end{array}$ & $\begin{array}{l}6 \\
6\end{array}$ \\
\hline $\begin{array}{l}\text { Mn: } \\
\text { (mg. } / 100 \mathrm{~g} . \text { of ash) } \\
\text { (mg. } / 100 \mathrm{~g} . \text { of } \mathrm{dry} \\
\text { fat-free bone) }\end{array}$ & $\begin{array}{l}474 \pm 13 \\
192 \pm 15\end{array}$ & $\begin{array}{l}861 \pm 19 \\
450 \pm 12\end{array}$ & $\begin{array}{l}904 \pm 18 \\
410 \pm 20\end{array}$ & $\begin{array}{l}906 \pm 24 \\
416 \pm 14\end{array}$ & $\begin{array}{l}956 \pm 18 \\
398 \pm 12\end{array}$ & $\begin{array}{l}404 \pm 20 \\
243 \pm 11\end{array}$ & $\begin{array}{l}\mathbf{3} \\
\mathbf{3}\end{array}$ & $\begin{array}{l}6 \\
6\end{array}$ \\
\hline
\end{tabular}

No. of pairs of No. of

$2.5 \mathrm{mg}$. of

$\mathrm{Mn} / \mathrm{kg}$. of meat

5.0 mg. of $\mathrm{Mn} / \mathrm{kg}$. of meat

$6 \cdot 0+0.9$

$20 \cdot 9 \pm 3 \cdot 2$

$23 \cdot 0 \pm 5 \cdot 0$

$10.0 \mathrm{mg}$. of $\mathrm{Mn} / \mathrm{kg}$.

$25 \cdot 0 \mathrm{mg}$. of $\mathrm{n} / \mathrm{kg}$. meat $3600 \mathrm{mg}$. of femurs in $\mathrm{Ca} / \mathrm{kg}$. of meat

$9 \cdot 3 \pm 1 \cdot 5$ $29 \pm 9 \cdot 5$

$43 \cdot 5 \pm 3 \cdot 6$

$19 \cdot 0 \pm 3 \cdot 6$

$28.9+0.15$

$2 \cdot 3 \pm 0 \cdot 22$

$32 \cdot 3 \pm 0 \cdot 17$

. $50 \cdot 16$

$31 \cdot 3 \pm 0 \cdot 16$

$37 \cdot 4 \pm 0 \cdot 18$

each sample

samples in each

ean

4 4 4 
supplementation with only $10 \mathrm{mg}$. of manganese $/ \mathrm{kg}$. had no effect. Both concentrations of manganese (10 and $25 \mathrm{mg}$. $/ \mathrm{kg}$.) increased the manganese content of ash and bone $(P<0.01)$. It follows that the addition of $25 \mathrm{mg}$. of manganese $/ \mathrm{kg}$. of meat considerably improves the calcification of bone even within 2 weeks.

Although no further weight increase was observed in mice maintained on the meat diet for 4 weeks, the mice whose diet was supplemented with calcium continued growing (Table 2). The addition of small amounts of manganese to the meat $(2 \cdot 5-5 \cdot 0 \mathrm{mg}$. $/ \mathrm{kg}$.) brought about some increase in weight, but larger amounts $(10.0-25.0 \mathrm{mg} . / \mathrm{kg}$.) had no effect. The increased bone calcification resulting from the addition of calcium to the meat, which was apparent after 2 weeks, became more evident after 4 weeks. Small additions of manganese also improved calcification, though to a smaller degree. They increased bone ash and the calcium and phosphorus contents of ash and of dry fat-free bone, and decreased the incorporation of radioactive calcium in bones and in bone calcium. Larger amounts of manganese, i.e. 10.0 and particularly $25.0 \mathrm{mg}$. $/ \mathrm{kg}$. of meat, brought amout smaller increases in bone ash and in the concentrations of calcium and phosphorus in bone and in ash. The calcium and phosphorus contents of the bones of mice that were fed on meat supplemented with $25 \mathrm{mg}$. of manganese $/ \mathrm{kg}$. were significantly $(P<0.01)$ lower than those of mice that received the 2.5 or $5.0 \mathrm{mg}$. $/ \mathrm{kg}$. supplement, and differed little from those found in animals kept on the unsupplemented meat diet. This is in contrast with the results obtained with the high concentration of manganese after 2 weeks. The bone manganese content was similar in the four groups that received manganese, irrespective of the concentration of manganese supplementation. The lowest concentration is apparently adequate for maximal storage of manganese in bone.

Prolonging the experimental period to 6 weeks (Table 3) widened the differences in weight increase and weight of femurs between mice raised on the unsupplemented meat diet and those kept on the same diet with calcium added. Small amounts of manganese $(2 \cdot 5-5 \cdot 0 \mathrm{mg} . / \mathrm{kg}$. of meat) slightly increased the amount $(P 0 \cdot 2-0 \cdot 05)$ and percentage $(P 0 \cdot 02-0.05)$ of bone ash, and decreased the incorporation of radioactive calcium in dry fat-free bone $(P<0.01)$ and in bone calcium $(P<0.01)$. Higher concentrations of manganese $(10 \cdot 0-25 \cdot 0 \mathrm{mg} . / \mathrm{kg}$. of meat) depressed growth and decreased the bone ash

Table 3. Composition of bones and uptake of radioactive calcium by femurs of mice maintained for 6 weeks on a meat diet

Experimental details are given in the text. The results are given as means \pm s.F.M.

\begin{tabular}{|c|c|c|c|c|c|c|c|c|}
\hline Supplement & None & $\begin{array}{l}2.5 \mathrm{mg} \text {. of } \\
\mathrm{Mn} / \mathrm{kg} \text {. of } \\
\text { meat }\end{array}$ & $\begin{array}{l}5 \cdot 0 \mathrm{mg} . \text { of } \\
\mathrm{Mn} / \mathrm{kg} . \text { of } \\
\text { meat }\end{array}$ & $\begin{array}{l}10 \cdot 0 \mathrm{mg} \text {. of } \\
\text { Mn } / \mathrm{kg} . \text { of } \\
\text { meat }\end{array}$ & $\begin{array}{c}25 \cdot 0 \mathrm{mg} \text {. of } \\
\mathrm{Mn} / \mathrm{kg} . \text { of } \\
\text { meat }\end{array}$ & $\begin{array}{l}3600 \mathrm{mg} \text {. of } \\
\mathrm{Ca} / \mathrm{kg} . \text { of } \\
\text { meat }\end{array}$ & $\begin{array}{c}\text { No. of } \\
\text { pairs of } \\
\text { femurs in } \\
\text { each } \\
\text { sample }\end{array}$ & $\begin{array}{c}\text { No. of } \\
\text { samples } \\
\text { in each } \\
\text { mean }\end{array}$ \\
\hline $\begin{array}{l}\text { Weight increase (g.) } \\
\text { Weight of femurs (mg.) }\end{array}$ & $\begin{array}{r}5 \cdot 4 \pm 1 \cdot 4 \\
98 \pm 9 \cdot 2\end{array}$ & $\begin{array}{r}6 \cdot 9 \pm 1 \cdot 1 \\
113 \pm 5 \cdot 5\end{array}$ & $\begin{array}{r}7 \cdot 1 \pm 1 \cdot 0 \\
109 \pm 5 \cdot 2\end{array}$ & $\begin{array}{r}6 \cdot 9 \pm 0 \cdot 6 \\
104 \pm 6 \cdot 8\end{array}$ & $\begin{array}{r}4 \cdot 2 \pm 0 \cdot 8 \\
111 \pm 5 \cdot 7\end{array}$ & $\begin{array}{r}13 \cdot 5 \pm 1 \cdot 0 \\
141 \pm 4 \cdot 4\end{array}$ & $\overline{1}$ & $\begin{array}{l}24 \\
24\end{array}$ \\
\hline \multicolumn{9}{|l|}{ Ash: } \\
\hline $\begin{array}{l}\text { (mg.) } \\
\text { (\% of dry fat-free } \\
\text { bone) }\end{array}$ & $\begin{array}{l}19 \cdot 8 \pm 1 \cdot 7 \\
44 \cdot 3 \pm 0 \cdot 41\end{array}$ & $\begin{array}{l}24 \cdot 2 \pm 1 \cdot 4 \\
46 \cdot 1 \pm 0 \cdot 63\end{array}$ & $\begin{array}{l}22 \cdot 7 \pm 1 \cdot 8 \\
45 \cdot 6 \pm 0 \cdot 58\end{array}$ & $\begin{array}{l}19 \cdot 6 \pm 1 \cdot 3 \\
39 \cdot 9 \pm 0 \cdot 50\end{array}$ & $\begin{array}{l}20 \cdot 0 \pm 0 \cdot 7 \\
37 \cdot 1 \pm 0 \cdot 65\end{array}$ & $\begin{array}{l}44 \cdot 0 \pm 1 \cdot 6 \\
59 \cdot 3 \pm 0 \cdot 73\end{array}$ & $\begin{array}{l}1 \\
1\end{array}$ & $\begin{array}{l}24 \\
24\end{array}$ \\
\hline \multicolumn{9}{|l|}{$\mathrm{Ca}:$} \\
\hline (\% of ash) & $32 \cdot 9 \pm 0.29$ & $32 \cdot 3 \pm 0 \cdot 37$ & $31 \cdot 4 \pm 0 \cdot 20$ & $30.7 \pm 0.21$ & $28.8 \pm 0.28$ & $41 \cdot 2 \pm 0.20$ & 1 & 24 \\
\hline $\begin{array}{l}\text { (\% of dry fat-free } \\
\text { bone) }\end{array}$ & $14 \cdot 5 \pm 0 \cdot 19$ & $15 \cdot 0 \pm 0.36$ & $14 \cdot 0 \pm 0 \cdot 24$ & $12 \cdot 1 \pm 0 \cdot 20$ & $10 \cdot 7 \pm 0 \cdot 13$ & $24 \cdot 5 \pm 0 \cdot 20$ & 1 & 24 \\
\hline $\begin{array}{l}\text { Ca incorporated: } \\
\text { ( } \mu \text { g./g. of dry fat- } \\
\text { free bone) }\end{array}$ & $72 \pm 0 \cdot 20$ & $67 \pm 0 \cdot 21$ & $67 \pm 0 \cdot 33$ & $64 \pm 0 \cdot 29$ & $70 \pm 0 \cdot 20$ & $39 \pm 0 \cdot 72$ & 1 & 6 \\
\hline $\begin{array}{l}\text { ( } \mu \mathrm{g} . / 100 \mathrm{mg} . \text { of } \\
\text { bone Ca) }\end{array}$ & $50 \pm 0 \cdot 29$ & $45 \pm 0 \cdot 11$ & $47 \pm 0.28$ & $52 \pm 0 \cdot 38$ & $63 \pm 0 \cdot 13$ & $17 \pm 0.55$ & 1 & 6 \\
\hline \multicolumn{9}{|l|}{ P: } \\
\hline $\begin{array}{l}\text { (\% of ash) } \\
\text { (\% of dry fat-free } \\
\text { bone) }\end{array}$ & $\begin{array}{r}17 \cdot 6 \pm 0 \cdot 42 \\
7 \cdot 6 \pm 0 \cdot 30\end{array}$ & $\begin{array}{r}17 \cdot 5 \pm 0 \cdot 28 \\
8 \cdot 0 \pm 0 \cdot 25\end{array}$ & $\begin{array}{r}16 \cdot 8 \pm 0 \cdot 12 \\
7 \cdot 8 \pm 0 \cdot 13\end{array}$ & $\begin{array}{r}16 \cdot 2 \pm 0 \cdot 12 \\
6 \cdot 2 \pm 0 \cdot 11\end{array}$ & $\begin{array}{r}15 \cdot 0 \pm 0 \cdot 09 \\
5 \cdot 8 \pm 0 \cdot 16\end{array}$ & $\begin{array}{l}20 \cdot 9 \pm 0 \cdot 21 \\
12 \cdot 2 \pm 0 \cdot 43\end{array}$ & $\begin{array}{l}\mathbf{3} \\
\mathbf{3}\end{array}$ & $\begin{array}{l}6 \\
6\end{array}$ \\
\hline $\begin{array}{l}\text { Mn: } \\
\text { (mg./100g. of ash) } \\
\text { (mg./100g. of dry }\end{array}$ & $\begin{array}{l}530 \pm 10 \\
236 \pm 19\end{array}$ & $\begin{array}{l}990 \pm 12 \\
456 \pm 14\end{array}$ & $\begin{array}{l}915 \pm 13 \\
432 \pm 22\end{array}$ & $\begin{array}{l}980 \pm 14 \\
381 \pm 33\end{array}$ & $\begin{array}{r}1087 \pm 24 \\
398 \pm 28\end{array}$ & $\begin{array}{l}475 \pm 4 \\
275 \pm 12\end{array}$ & $\begin{array}{l}\mathbf{3} \\
\mathbf{3}\end{array}$ & $\begin{array}{l}6 \\
6\end{array}$ \\
\hline
\end{tabular}


and calcium and phosphorus contents of bone. At the highest concentration of manganese supplementation, the incorporation of radioactive calcium in bone calcium was increased. It therefore appears that relatively large doses of manganese are toxic when administered over a prolonged period and induce defective calcification of bone. The manganese content of bone was similar to that found after 4 weeks.

\section{DISCUSSION}

Our results confirm and extend previous observations (Ilan et al. 1961) that young mice kept on a meat diet develop an osteoporosis-like condition that can be prevented by the addition of calcium to the meat. In the absence of any supplement bone ash and calcium and phosphorus concentrations of bone decrease and the incorporation of radioactive calcium by bone becomes higher than when calcium is added. These changes suggest decreased calcification (Carlsson, 1951; Menczel, Schraer, Pakis, Posner \& Likins, 1963). The possibility that the addition of unlabelled calcium to meat would dilute the concentration of radioactive calcium in the serum cannot be excluded, although the serum calcium concentration was not found to be affected by the meat diet (Ilan et al. 1961). The addition, over a period of 4 weeks, of small amounts of manganese $(2 \cdot 5-5 \cdot 0 \mathrm{mg} . / \mathrm{kg}$.) to the meat diet improves calcification of bone. The possibility that these supplements of manganese affected food intake and thus calcification cannot be excluded. However, the nature of the diet used, namely raw minced meat, made an exact measurement of food consumption unreliable. After 6 weeks no clear effect on the bone composition is discernible, although the incorporation of radiocalcium is increased. The same supplementation concentration, i.e. $2.5 \mathrm{mg}$. $/ \mathrm{kg}$., was found by Ilan et al. (1961) to increase bone ash even after a 6-week observation period.

The deleterious effect exerted by a meat diet on the skeleton of kittens (Scott, Greaves \& Scott, 1961) and of rats (Moore \& Sharman, 1960) has been reported. Growth of rats ceased after a few weeks, and the bones were undersized, had thin walls and a low ash content and were often fractured. The disorder could be prevented by adding adequate amounts of calcium to meat (Moore et al. 1962). Our results indicate that not only calcium is involved. Muscle meat is a poor source of manganese (Underwood, 1962). Radiographic, histological and biochemical investigations have established the important role of manganese in osteogenesis (Underwood, 1962). Dietary lack of manganese is reported to inhibit growth and to cause poor calcification of bone in mice, rats and rabbits (Shils \& McCollum, 1943; Wachtel, Elvehjem \& Hart,
1943; Smith \& Ellis, 1947). Skeletal maturation of the young is retarded (Frost, Asling \& Nelson, 1959), and the density, breaking strength and ash content of bones is decreased. Microscopically, extensive deviations from normal were found that were interpreted as suppressed osteogenesis rather than as accelerated bone resorption (Smith, Medlicott \& Ellis, 1944).

As mentioned above, these findings were reported in animals that had subsisted on manganese-deficient diets containing adequate amounts of calcium. The fact that meat is deficient in manganese as well as in calcium renders it particularly suitable for studying the effect of manganese on bone calcification and calcium metabolism without interference by calcium. In mice maintained on meat small amounts of manganese play an important role in calcification, whereas larger doses lead apparently to defective calcification of newly formed bone.

The larger doses are, however, much smaller than those reported to be toxic for guinea pigs $(500 \mathrm{mg}$. $/ \mathrm{kg}$ of food), rats (over $2000 \mathrm{mg}$./kg.) and chicks (4800 mg. $/ \mathrm{kg}$.) (Underwood, 1962). It is possible that the increased sensitivity of our animals results from the low calcium content of their diet, and that no adverse effects on bone would have been observed if the diet had provided adequate amounts of calcium.

This study was supported by U.S. Public Health Service Research Grant A-4385 from the National Institutes of Health, Bethesda, Md., U.S.A.

\section{REFERENCES}

Baron, D. N. \& Bell, J. L. (1959). J. clin. Path. 12, 143. Carlsson, A. (1951). Acta pharmacol., Kbh., 7, suppl. 1.

Fiske, C. H. \& Subbarow, Y. (1925). J. biol. Chem. 66, 375. Frost, G., Asling, C. W. \& Nelson, M. M. (1959). Anat. Rec. 134, 37.

Gates, E. M. \& Ellis, G. H. (1947). J. biol. Chem. 168, 537. Ilan, J., Schwartz, A. \& Guggenheim, K. (1961). Metabolism, 11, 535.

Menczel, J., Schraer, R., Pakis, G., Posner, A. S. \& Likins, R. C. (1963). Proc. soc. exp. Biol., N.Y., 112, 128.

Moore, T. \& Sharman, I. M. (1960). Brit. med.J. ii, 1704.

Moore, T., Sharman, I. M., Constable, B. J., Symonds, K. R., Martin, P. E. N. \& Collinson, R. (1962). J. Nutr. 77, 415. Scott, P. P., Greaves, J. P. \& Scott, M. G. (1961). Brit. J. Nutr. 15, 35.

Shils, M. \& McCollum, E. V. (1943). J. Nutr. 26, 1.

Smith, S. E. \& Ellis, G. H. (1947). J. Nutr. 34, 33.

Smith, S. E., Medlicott, M. \& Ellis, G. H. (1944). Arch. Biochem. 4, 281.

Ulmansky, M. (1964). Amer.J. Path. 44, 85.

Underwood, E. J. (1962). Trace Elements in Human and Animal Nutrition, 2nd ed., chapter 7. New York: Academic Press Inc.

Wachtel, L. W., Elvehjem, C. A. \& Hart, E. B. (1943). Amer.J. Physiol. 140, 72.

Bioch. 1965, 95 